Who gets the Top Jobs? The role of family background and networks in recent graduates' access to high status professions

Lindsey Macmillan

Claire Tyler

Anna Vignoles

Department of Quantitative Social Science

Working Paper No. 13-15

December 2013 


\section{Disclaimer}

Any opinions expressed here are those of the author(s) and not those of the Institute of Education. Research published in this series may include views on policy, but the institute itself takes no institutional policy positions.

DoQSS Workings Papers often represent preliminary work and are circulated to encourage discussion. Citation of such a paper should account for its provisional character. A revised version may be available directly from the author. 


\title{
Who gets the Top Jobs? The role of family background and networks in recent graduates' access to high status professions
}

\author{
Lindsey Macmillan ${ }^{1}$, Claire Tyler ${ }^{2}$ and Anna Vignoles ${ }^{3}$
}

\section{Abstract}

There is currently a debate in policy circles about access to "the upper echelons of power" (Sir John Major, ex Prime Minister, 2013). This research seeks to understand the relationship between family background and early access to top occupations. We find that privately educated graduates are a third more likely to enter into high status occupations than state educated graduates from similarly affluent families and neighbourhoods. A modest part of this difference is driven by educational attainment with a larger part of the story working through the university that the privately educated graduates attend. Staying on to do a Masters and higher degree is also a (smaller) part of the picture. We explore one potential mechanism which is often posited as a route in accessing top jobs: the role of networks. We find that although networks cannot account for the private school advantage, the use of networks provides an additional advantage over and above background and this varies by the type of top occupation that the graduate enters. A private school graduate who uses personal networks to enter into a top managerial position has a 1.5 percentage point advantage (on a baseline 6.1\%) over a state school graduate who uses other ways to find their job.

JEL classification: J62, L14

Keywords: intergenerational mobility, social mobility, networks

\footnotetext{
${ }^{1}$ Department of Quantitative Social Science, Institute of Education, University of London (L.macmillan@ioe.ac.uk)

${ }^{2}$ Department of Quantitative Social Science, Institute of Education, University of London (ctyler@ioe.ac.uk)

${ }^{3}$ Faculty of Education, University of Cambridge (ㅁv404@ cam.ac.uk)

Acknowledgements:

This work was part-funded by the Social Mobility and Child Poverty Commission. We are grateful for comments from John Micklewright, Paul Gregg and contributors to the Intergenerational Mobility and Social Gradients in Children's Life Chances conference hosted by the Social Mobility and Child Poverty Commission and the Centre for Market and Public Organisation, University of Bristol.
} 


\section{Introduction}

The UK government has stated that its aim is to create a society in which each individual, regardless of background, has an equal chance of realising their potential (Cabinet Office, Opening Doors Breaking Barriers: A Strategy for Social Mobility) ${ }^{4}$. However, the UK labour market displays relatively low intergenerational income mobility, high income inequality and educational attainment varies significantly by socioeconomic background (Ermisch et al. 2012). Whilst the UK is not alone in facing these problems, they are arguably more acute in the UK than in many other European countries. In this paper we investigate one aspect of this UK social mobility problem, namely the relationship between graduates' family background and their access to high status occupations.

We define exactly what we mean by high status occupation below but broadly these are occupations that tend to have the highest earnings, job security and better longer-term income prospects (Goldthorpe and McKnight, 2006, Bukodi and Goldthorpe, 2011a). In this paper we make a contribution to the literature by focusing on the extent to which family background is correlated with being employed in one of these specific occupations for a recent cohort of graduates, even after allowing for education achievement. Previous work on the relationship between socio-economic background, education achievement and occupational outcomes has focused on occupational status more generally, rather than access to the most elite professions. We also add to the evidence base by assessing whether social networks play a significant role in perpetuating any unequal access to these jobs. We use data from the Higher Education Statistics Agency ${ }^{5}$ on first degree graduates leaving higher education in 2006/7 and who have been surveyed at 6 months and around 3.5 years after graduation. The data includes students graduating from Scottish, English and Welsh institutions.

The policy background to this work is the significant increase in the size of the graduate labour market in the UK. Despite the increase in university participation during the last 40 years, the average wage return to a degree remains high in the UK (Bratti and Manchini 2003; Bratti et al 2005; Chevalier 2010, 2011; Walker and Zhu 2005, 2011). Hence for many, a degree continues to be the route to a high paid job. Yet we also know that access to some professions is unequal, with graduates from less advantaged backgrounds being less able to make the transition into these higher paying, prestigious and more stable jobs. This problem

\footnotetext{
${ }^{4}$ https://www.gov.uk/government/publications/opening-doors-breaking-barriers-a-strategy-for-social-mobility.

${ }^{5}$ The Longitudinal Destination of Leavers from Higher Education.
} 
has long been recognised in the academic literature on social mobility, and more recently has been highlighted to policy-makers by Alan Milburn in his 2009 report on fair access to the professions $^{6}$. His recent update ${ }^{7}$ confirms that there is much still to be done in terms of achieving fair access to professions. Specifically, individuals from more advantaged socioeconomic backgrounds continue to be more likely to secure a higher paid professional role, with many employers recruiting from a very limited range of universities and degree subjects. This undoubtedly has implications for social mobility, a point recognised in the recent White Paper (Cabinet Office, 2011). Whilst the descriptive evidence of the limited representation of poorer graduates in top professions is quite extensive, there is little analysis of the relative importance of education achievement in explaining these differences, as distinct from other factors, such as the use of social networks. In this paper we contribute new evidence on this issue, exploring the relative importance of educational achievement and social networks in explaining the socio-economic gap in access to top professions.

This analysis will inform policy. The Government has introduced 'access to the professions' and 'graduate destinations by social background' as two national social mobility indicators, with the aim of providing an overall assessment of the success of subsequent government policies in this area (Cabinet Office, 2013; Gregg \& Macmillan, 2012). These policies have sought to promote fair access to the professions through a range of measures including widening higher education participation, formalising work experience opportunities, reforming recruitment and selection processes, promoting flexible entry and progression routes, enhancing information and career guidance and raising aspirations of young people. Our work cannot comment on the success of these measures since our data pre-date their introduction. Nonetheless our analysis can provide policy-makers with a baseline estimate of the extent of any unequal access to the professions and possible reasons for such inequality.

It is worth noting that this issue crosses discipline borders. The economic literature has largely focused on estimating the wage return to a degree, rather than on the specific occupations held by graduates. Sociologists by contrast have focused on occupational mobility. There is of course a long standing debate between sociologists and economists about how best to measure social mobility and whether we should be focusing largely on earnings or on occupational status (Blanden et. al., 2013; Goldthorpe and Jackson 2007;

\footnotetext{
${ }^{6}$ http://webarchive.nationalarchives.gov.uk/+/http://www.cabinetoffice.gov.uk/media/227105/fair-accesssummary.pdf. See also Macmillan (2009).

${ }^{7}$ http://www.cabinetoffice.gov.uk/sites/default/files/resources/IR_FairAccess_acc2.pdf
} 
Goldthorpe and Mills, 2008; Gorard, 2008; Erikson and Goldthorpe, 2010; Goldthorpe, 2013). In this paper we do not attempt to answer this question. Instead, we acknowledge that securing a top managerial or professional job leads to higher earnings, more job security and good long-term income prospects (Goldthorpe and McKnight, 2006). It is also a major route by which graduates earn a high return to their degree (Bukodi and Goldthorpe, 2011a). We therefore need better understanding about early access to these high status occupations both because it will influence the occupational status of the individual but also because it will have a major impact on their lifetime earnings. A further issue is that in the UK until recently we lacked good data on the lifetime earnings of graduates (Crawford et al. 2013). We would argue that assessing transitions into occupations that are known to have good long run economic prospects is one way to get partially around this data problem.

\section{Related Literature}

This paper contributes to the extensive labour market research that has identified low levels of intergenerational income mobility and high income inequality in the UK (Blanden et al, 2004; Blanden et al 2005; Blanden \& Machin 2004; Blanden et al, 2013; Bjorklund et al, 2005; Ermisch and Nicoletti, 2005; Crawford et al, 2011). Educational attainment in the UK also varies significantly by socioeconomic background (Gregg and Goodman 2010; Gregg and Macmillan 2010; Goodman et al, 2011; Chowdry et al 2010, Chowdry et al 2012; Crawford et al 2010; Jerrim 2012) and is particularly influenced by family background in early childhood (Feinstein 2003a and 2003b, Blanden 2006, Gregg et al 2008). This holds true across most countries but the relationship between family background and educational and economic outcomes is arguably somewhat stronger in the UK (Jerrim, 2012, Gregg et. al., 2013). Understanding the characteristics of the UK education system and labour market that create barriers to social mobility have therefore become important policy targets in the government's pursuit of improved social mobility (Cabinet Office, 2011).

Our research focuses on a specific, and under research issue, namely fair access to managerial and professional careers and within this group, the most elite professions. Managerial and professional careers are of particular national interest as they are expected to account for approximately two million additional jobs in the next decade, increasing their share of total employment in the UK from 42\% to 46\% (Wilson and Homenidou, 2011; Brewer et al, 2012). To date, while there has been a number of official reports published on this topic (Cabinet Office, $2009 \&$ 2012), there have been relatively few academic studies that have 
highlighted potential barriers specifically to professional careers (Langlands, 2005; Sutton Trust, 2005 and 2006). Macmillan (2009) found an increase in the proportion of professionals originating from wealthier families between 1958 and 1970 in nine of the 12 professions examined. Specifically, the highest socially graded professions (medicine and law) became even more exclusive, and journalism, banking and accounting showed large increases in exclusivity to become highly socially graded professions. Bukodi and Goldthorpe (2011b) highlight the influence of education, particularly higher tertiary qualifications, and class origin on access to the salariat (defined as NS-SEC classes 1 and 2). However, as they acknowledge, their analysis would further benefit from also including women and taking greater account of the specific qualifications and non-cognitive characteristics of individuals. We therefore build on their work, focusing on these higher level occupations but incorporating analysis of female graduates and isolating the relationship between SES and occupation by taking fuller account of individuals' school and university achievement, including subject of degree and institution attended.

A broader investigation of social mobility by Breen and Goldthorpe (1999) highlighted the role of merit in mobility processes, concluding that children of disadvantaged class origins have to display far more merit than children of more advantaged origins in order to attain similar class positions. More recently, despite relationships weakening over time, Devine and Li (2013) report persistent significant relationships between class origins and both education attainment and class destinations. As discussed, we contribute to this broader social mobility literature directly by investigating whether these types of findings hold even for similarly high achieving UK graduates.

One particular concern for policy makers is the extent to which barriers to professional careers are created by the lack of access to relevant personal and professional networks for young people from more disadvantaged backgrounds. Numerous theoretical contributions have sought to model the influence of networks on labour market outcomes (Montgomery, 1991; Calvo-Armengol, 2004 and 2007; Calvo-Armengol and Jackson, 2004; Casella and Hanaki, 2005) forming part of a wider body of search theory literature aiming to model job seeking behaviour (Stigler, 1961 and 1962; Pissarides, 2001). Networks represent informal channels of job search including employee referrals and social connections (Rees, 1966) and are one important element of social capital (Loury, 1977; Coleman, 1990). These channels are considered to be among the most productive and low cost methods of generating job offers 
(Holzer, 1988), with benefits for income and job tenure (Loury, 2006). Ioannides and Loury (2004) outline the widespread use of networks and also illustrate the complexity of assessing their role in job searches, including significant variation in the usage and productivity of networks between job seekers. The usage and effectiveness of networks depends on the characteristics of the individual, the nature of their contact (Lin, 2001), their relationship with the contact (Granovetter, 1973, 1974 and 1995) and the work environment such as industry, corporate culture and occupational grouping (Fernandez and Castilla, 2001; Marsden and Gorman, 2001).

Empirical work on the role of networks in providing job search advantages can be found in international research on the extent to which children are employed in the same organisations as their parents. Specifically in Canadian and Danish labour markets, the transmission of employers from father to son is found to be positively associated with paternal earnings, rising distinctly and sharply at the top of the father's earnings distribution (Bingley, Corak and Westergård-Nielsen, 2011). Corak and Piraino (2010) also find that almost $70 \%$ of the sons of top percentile fathers have at some point worked for a firm that also employed their fathers and they highlight the significant incidence of family based succession in CEOs in the US. Using Swedish data, Kramarz And Skans (2006) also find that family networks play an important role in the transition from work to employment.

Within the UK policy arena, specific concerns surround the role of networks in creating barriers to professional careers due to the numerous advantages they provide for successful job seeking through both formal and informal channels. It is argued that it is often networks, rather than academic ability, that provide privileged access to valuable work experience opportunities. Graduates with early access to these networks can therefore benefit from both the intrinsic and signalling value of the work experience, and the opportunity to access further networking opportunities. For example, Mann (2012) found that young people in the UK who have had regular contact with employers while in education are found to be five times less likely to be NEET ('not in education, employment or training') and earn, on average, $16 \%$ more than their peers. The importance of finding work experience, internships and placement opportunities is also regularly highlighted by national reviews and graduate recruitment research (Wilson, 2012; Wolf, 2011; Association of Graduate Recruiters, 2011; CBI, 2011; High Fliers Research, 2011). Relevant literature therefore suggests that use of personal and professional networks is a potentially influential determinant of securing a 
professional career. This paper contributes to this empirical evidence for the UK by assessing the use of networks amongst a cohort of recent graduates, providing an analysis of the extent to which the use of networks is socially graded even amongst recent graduates and estimating whether use of networks explains a significant proportion of the socio-economic gap in access to high status occupations. Though not providing causal analysis, this paper does nonetheless provide some indicative evidence on whether lack of networks is likely a major socio-economic barrier to professional careers in the UK.

\section{Data}

We use data from the Destinations of Leavers from Higher Education (DLHE) 'early' and 'longitudinal' surveys carried out by the UK Higher Education Statistics Agency (HESA) to analyse the association between family background, use of networks and entering higher status occupations. We specifically focus on the surveys for leavers from higher education in 2006/2007. These surveys target all UK and EU domiciled students reported to HESA for the period 1 August 2006 to 31 July 2007, including full time and part time and undergraduate and postgraduate students, however excluding students studying for professional qualifications. The 'early survey' is conducted approximately 6 months after graduation ${ }^{8}$, with a total 453,880 leavers who were eligible to take part, of which $332,110(73.2 \%)$ responded: the response rate is in line with previous years (HEFCE, 2011). A longitudinal survey is conducted up to 3.5 years after graduation ${ }^{9}$ for sub-samples of students who responded to the early DLHE survey. This longitudinal survey captured 49,010 valid responses ${ }^{10}$. Of these, we have limited our sample to 24,980 graduates (including PT students) who finished higher education in 2006/2007 during the reference period; completed the survey at 3.5 years after graduation; studied for an undergraduate degree; were aged 1825 on $31^{\text {st }}$ July 2007 and have occupational data (SOC 2000) available at 3.5 years after graduation. Appendix Table A1 suggests that this restricted sample looks very similar to the early sample of HESA data in terms of family background characteristics.

With these data we are able to provide new insight into the role of family background and networks as a barrier to fair access to high status jobs for this sample of young graduates at

\footnotetext{
${ }^{8}$ Reference dates of 16 April 2007 (if the leaver obtained the qualification between 1 August 2006 and 31. December 2006) and January 2008 (if the leaver obtained the qualification between 1 January 2007 and 31 July 2007).

${ }^{9}$ Reference date $29^{\text {th }}$ November 2010 .

${ }^{10}$ The HESA technical report indicates that the pattern of non response meant that women were more likely to respond than men, as were older graduates, white graduates and by subject and institution (HESA, 2009).
} 
3.5 years after graduation. We focus our analysis on graduates some 3.5 years after graduation because in the period immediately after graduation there is likely to be a period of transition as graduates make their way into the labour market. Some may take temporary jobs or indeed no job at all. We are more confident that their occupation a few years after graduation is likely to be a better guide to their future occupational status.

The occupational status of graduates at 3.5 years after graduation is measured using 5-digit SOC 2000 codes. We aggregate this very detailed occupational information into a form that enables us to more confidently rank the social and economic status of occupations. Specifically, from this data, we assign each individual an analytical National Statistics Socioeconomic Classification (NS-SEC) code 1 to $7^{11}$ which allows us to create some ranking of occupations by employment relations. Individuals' positions within this scale have been shown to be a major influence on their economic life chances (Chan and Goldthorpe, $2007)^{12}$. We primarily define high status ${ }^{13}$ occupations as those in the top NS-SEC grouping (around $30 \%$ of the total sample of graduates ${ }^{14}$ ). Within this definition of high status occupations we consider differences in the role of family background on three separate groups of occupations: a) higher managerial (NS-SEC 1.1 occupations), b) business, legal and life science occupations and c) educational, built environment, scientist and additionally any other occupations identified by the Social Mobility and Child Poverty Commission as a distinct group of high status careers. Details of occupations within these groupings are given in the Appendix. These high profile occupations are often the focus of government policies for promoting fair access. In addition there are clear differences in the labour market reward by groups of occupations: on average higher managerial occupations earned $£ 73,000$ over the course of 2011 compared to $£ 51,000$ for business, legal and life science professions and $£ 39,000$ for education, built environment, scientists and other higher professions ${ }^{15}$. One option followed by some economists would have been to provide estimates of lifetime earnings for each occupational group and to use these expected earnings as our outcome

\footnotetext{
${ }^{11}$ Due to the lack of data on employment status we are restricted to using the simplified method of conversion between SOC 2000 and NS-SEC. This has around 88\% success rate compared to the full method of conversion. ${ }^{12}$ Measures of earnings at age 25 may suffer from significant biases due to age-earnings profiles and therefore understate the true role of family background (Haider and Solon, 2006). Of course, occupation is likely to also change across the life-cycle although appears stable after age 30 (Bukodi, Dex and Goldthorpe, 2011).

${ }^{13}$ We acknowledge that status commonly refers to an alternative concept of social honour in the sociological literature (Chan and Goldthorpe, 2007).

${ }^{14}$ The graduate group is of course a select sub sample of this cohort. Approximately one in five of 18-19 year olds in this cohort enrolled in a full time first degree.

${ }^{15}$ Data taken from the Annual Survey of Hours and Earnings (ASHE) average annual earnings for 2011 for all workers by 4 digit SOC code.
} 
measure. However, our intention here is to consider both the social and the economic status of occupations as summarised by the NS-SEC scale, though recognising that the social status of jobs are also implicated in the higher earnings achieved by most higher level occupations. Table 1 shows the proportion of graduates in our sample employed in these high status occupations and in other jobs at 3.5 years after graduation (column 1).

We have three measures of family background available in the data: parental NS-SEC, the neighbourhood participation rate in higher education and type of secondary school attended. The parental occupation variable is created based on the occupational category (as measured by SOC2000), the size of the employer, employment status (employer, self-employed or employee) and supervisory responsibility of the highest-status parent. Undergraduate students entering higher education through UCAS are asked to provide information on their parents' occupations, though clearly some choose not to do this, particularly mature students. Further, this information may be systematically misreported if students consider there to be advantages in the application process to over-stating or under-stating the occupation of their parents. In fact the UCAS application process makes it clear that these data on students' SES background are not used for selection purposes, though students may not be fully aware of this. This may explain the relatively high rate of missing data. Missing parental NS-SEC data (18.8\% of our final sample) comprises graduates for whom the occupation of their parents is either unclassified (14.4\%) or unknown (4.4\%). 'Unclassified' NS-SEC represents either students or other occupations which are not stated, inadequately described or not classifiable for other reasons. 'Unknown' NS-SEC is likely to comprise 'non-typical' students who do not enter higher education through UCAS and for whom parental NS-SEC data has not been separately reported to HESA by their institution.

Appendix Table A2 illustrates the proportion of our sample missing information on family background across our main occupation groups of interest. The extent of missing data is identical in top NS-SEC occupations compared to NS-SEC 2-7 jobs. Missing dummies are included in all models to control for this missing data. Our measure of neighbourhood higher education participation is based on the POLAR3 classification which contains rankings of higher education participation by area (Census Area Statistic wards). From this, quintiles of areas are constructed, ordered from ' 1 ' (those with lowest participation) to ' 5 ' (those with 
highest participation). School type is measured as students entering higher education from private (independent) schools and those entering from state schools ${ }^{16}$.

Table 1 (columns 2-7) shows the socioeconomic background of graduates in our sample employed in high-status occupations compared to those employed in NS-SEC 2-7 occupations 3.5 years after graduation. Those who worked in high status occupations were somewhat more likely to come from a family with professional or managerial parents (NSSEC 1 and 2) than those working in a lower NS-SEC (62.5\% top NS-SEC compared to 57.7\% NS-SEC 2-7). They were also less likely to come from a low HE participation area (6.2\% compared to $8.1 \%$ ). Graduates entering high status occupations were also markedly more likely to have attended a private school compared to those in other graduate jobs (16.9\% compared to $10.8 \%$ ). It is important to note that even within the top NS-SEC occupation (group 1), there are notable differences in the family background of those entering alternative high-status careers. For example, $62.7 \%$ of those graduates entering higher managerial occupations had a parent in NS-SEC 1 or 2 but within the higher professional occupations, this ranges from $67.9 \%$ of graduates entering the legal profession to $57.5 \%$ of graduates becoming scientists. Similarly, in terms of the type of school attended, only $8.2 \%$ of scientists and $11.1 \%$ of build environment graduates attended a private school compared to $20.4 \%$ of higher managerial graduates, $21.3 \%$ of legal graduates and $23.7 \%$ of graduates entering the business profession. We consider these important differences within the top NSSEC occupations in our models by considering a more disaggregated set of groupings as set out above (see Appendix for full occupation listings).

When considering the role of networks in accessing high status professions, we use information on the channels used to find out about the job in which they were employed at 3.5 years after graduation. Three types of network are identified in the survey, namely professional networks (professional, work or educational contacts or networks), personal networks (personal contacts, including family, friends and social networks) and already or previously having worked for the organisation (which may reflect use of previous professional or personal networks). All estimates of the effects of networks on occupational status are therefore stated in relation to students who found out about their job in 'other ways' i.e. specifically using non-network channels, defined as using a recruitment agency, career service, employer website, media advertisement, speculative application or other method.

\footnotetext{
${ }^{16}$ Schools not classified as independent are deemed to be state schools, therefore students from selective grammar schools, sixth forms and further education colleges are also included as state schools.
} 
Table 2 shows the use of different types of networks by the graduates in our sample who were employed in top NS-SEC occupations (column 1), high status occupations within the top NSSEC (columns 2-4) and other graduate jobs (NS-SEC 2-7, column 5). It is clear that networks are an important channel for graduates obtaining information about job opportunities for all types of occupations with over $30 \%$ of graduates finding their jobs this way across all groups. However, there are differences in the type of network used across the types of job graduate end up in. Professional networks are used by $11.2 \%$ of those working in the top NS-SEC compared to $8.2 \%$ in NS-SEC 2-7 occupations. Personal networks are actually used less in top NS-SEC jobs than in lower NS-SEC 2-7 jobs but within top NS-SEC jobs they are used by $16.1 \%$ of graduates entering higher managerial occupations compared to $10.5 \%$ of graduates entering business, legal and life-science professions. The main alternative way of finding out about a job is through career services, their websites or employers' websites. In reality, graduates are likely to have used numerous channels to find out about their job however the DLHE survey only permits one channel to be reported. This limits the amount of network data available and does not enable identification of graduates who use several types of networks. It is also possible that graduates may systematically under-report their use of networks due to the negative associations in the media and the perception of not gaining employment on the basis of merit alone. These two measurement issues together indicate that the true propensity of graduates to use networks may be even higher than is observed in our analysis. The extent to which differences in use of networks drives any socio-economic difference in access to high status occupations will be considered in our results.

\section{Methodology}

We hypothesise, drawing on human capital theory, that more socio-economically advantaged students will acquire more human capital and this in turn will enable them to access top jobs to a greater extent than students from more disadvantaged backgrounds. To the extent that we can control for individuals' human capital however, we might still expect socio-economic background to have an additional independent impact on the likelihood of getting into a top job. This might occur if more socio-economically advantaged students can afford to invest greater resource in their job search for example, taking more time to secure the top job they want. Sociological theories would also suggest that more socio-economically advantaged students will secure top jobs to a greater extent because they have greater levels of social capital. We cannot measure all aspects of students' human and social capital but we are able 
to assess whether they use networks to secure their job and we use this as a proxy for their social capital.

\section{Family background and accessing the top jobs}

We therefore begin by considering the raw association between family background and entering into a top job up to three and a half years after graduation. This association captures the overall relationship between family background and securing a top job, regardless of the mechanisms driving this relationship. Given that entry to a top NS-SEC job is a binary variable we estimate equation (1) using a probit model, where $F($.$) is the cumulative normal$ distribution and $\mathrm{X}$ represents a vector of family background characteristics including parental NS-SEC, quintiles of neighbourhood-level participation in higher education and a state school indicator.

$F\left(\right.$ Top_job $\left._{i}^{\text {child }}\right)=\alpha+\beta X_{i}^{\text {family }}$

The estimated parameters are presented as marginal effects, indicating the percentage point change in the probability of entering a top job for a unit change in $\mathrm{X}$.

We present estimates from models using pooled samples of male and female graduates. This maximizes our sample sizes. Males and females make different occupational choices and have different lifetime earnings. However, our data is from the early years of graduates' careers when the gender wage gap is approximately zero (Manning and Swaffield, 2008) and by implication occupational choices are more similar. For robustness we also estimated the models separately by gender: the coefficients on the variables of interest are not statistically significantly different from one another ${ }^{17}$ though the smaller sample size does cause some coefficients to become statistically insignificantly different from zero (Appendix Table A4).

While the raw association between family background and securing a top job is informative, ideally we would like to measure the association between socio-economic background and securing a top job allowing for the individual's human capital. More generally we may be concerned that there are also other factors associated with family background and the chances of entering into a top job that are driving our association. Given the richness of the data available, we can add potential confounders to our model to control for observable differences across graduates as shown in equation (2). We add these in four blocks, first we

${ }^{17} \mathrm{Z}$ score testing the difference between the two coefficients $=0.48$ 
include demographic controls ( $D=$ ethnicity, age and gender). We then add controls for human capital as measured by the student's prior attainment, $A$, including UCAS tariff, subject of degree study and degree class. We do this with the aim of removing differences in access to top jobs driven by the academic achievement of the candidate and the subject specialism. In our third model, we control for institution effects $(I)$ to condition on the choice of institution and region. This is to reflect the fact that all degrees are not equal and studying at prestigious institutions can provide an additional advantage to students in terms of future employment and controlling for institution attended addresses this. Finally, given the recent rise in postgraduate qualifications, we also condition on the type of postgraduate study undertaken up to 3.5 years after graduating $(P G)$ to assess whether this is an important route into the top jobs and if this can account for differences in entry to top jobs by family background. Missing dummies are included in all models.

$F\left(\right.$ Top $\left._{-} j o b_{i}^{\text {grad }}\right)=\alpha+\beta X_{i}^{\text {family }}+\gamma D_{i}^{\text {grad }}+\delta A_{i}^{\text {grad }}+\rho I_{i}^{\text {grad }}+\tau P G_{i}^{\text {grad }}$

The inclusion of these control variables in our models allows a 'like for like' comparison of graduates to be presented, at least in terms of observed characteristics. For example, professional firms often claim they recruit graduates based on academic attainment. As such, controlling for degree class, subject choice and prior attainment ensures the chances of similar graduates entering the professions are being estimated. Controlling for institution effects takes this one step further, ensuring that similar graduates from similar institutions are being compared. The results therefore show whether or not socioeconomic background has an effect on occupational status over and above these controls. However, despite our attempts to eliminate the impact of other factors on occupational status, graduates are still likely to differ in many ways which are not controlled for, in particular in their aspirations and other aspects of non-cognitive ability, all of which may be influential in securing a professional career. We cannot control for these unobserved sources of selection bias in our model and we return to this issue in our conclusions.

When we move on to analyse entry to higher managerial occupations, business, legal and life science occupations and education, science, built environment and other occupations compared to other graduate jobs (NS-SEC 2-7) we use a multinomial logit model, again presenting population average marginal effects of the probability of entering each occupation group relative to entering an NS-SEC 2-7 job. As is well known, the multinomial logit model requires the assumption of the independence of irrelevant alternatives (IAA). This implies 
that the likelihood of preferring one occupational group over another must not depend on the availability of other irrelevant alternatives. We believe that choice of occupation is dependent on a number of factors, including the human and social capital available to the individuals, and as such the existence of alternative occupation groupings is sufficiently independent to the individuals' choice, given their capital.

\section{The role of networks in accessing top jobs}

One factor that may be missing from the model is a measure of the student's social capital, which might also explain why socio-economically advantaged students are more likely to secure a top job. We add a measure of social capital, namely the student's use of networks to get their job. We consider whether networks $(N)$ can account for any of the socio-economic gradient in accessing the top jobs or whether they have an independent effect over and above family background. We do this by including the network measures to model (2) as shown below.

$F\left(T o p_{-} j o b_{i}^{\text {grad }}\right)=\alpha+\beta X_{i}^{\text {family }}+\sigma N_{i}^{\text {grad }}+\gamma D_{i}^{\text {grad }}+\delta A_{i}^{\text {grad }}+\rho I_{i}^{\text {grad }}+\tau P G_{i}^{\text {grad }}$

If higher socio-economic status graduates are entering the top jobs predominantly by accessing these jobs through their connections then the inclusion of networks in the model should diminish the direct effect of family background on the likelihood of entering a top job. If networks significantly predict entrance into top jobs but the socio-economic gap remains intact then this indicates that these are being used in addition to other benefits from coming from a high-status background to gain access.

\section{Results}

Family background and accessing the top jobs

Column 1 of Table 3 presents the marginal effects from our baseline probit model in equation (1) to show the raw socio-economic gradient in access to top jobs before conditioning on any further characteristics ${ }^{18}$. Graduates with a parent in a top NS-SEC occupation are 4.7

\footnotetext{
${ }^{18}$ Note that we include parental NS-SEC, neighbourhood participation and state school indicators together from the outset as we believe that each measure is contributing additional information regarding the family's socioeconomic status. The pseudo R-squared for parental NS-SEC alone is 0.003 , for neighbourhood participation alone is 0.005 and for state school indicator alone is 0.005 . Attending a state school has a correlation of 0.31 with parental NS-SEC, 0.09 with neighbourhood participation and parental NS-SEC and neighbourhood participation have a correlation of 0.11 .
} 
percentage points more likely to be working in a top NS-SEC occupation (baseline 30\%) themselves compared to graduates whose parent works in a routine occupation. There are no other significant effects by parental NS-SEC although graduates whose parents were longterm unemployed are 17.2 percentage points less likely to work in a top NS-SEC occupation compared to graduates with routine occupation parents (note the unemployed parent group is very small). A socio-economic gradient also exists in terms of the neighbourhood measure of HE participation. A graduate from a low participation area is 3.1 percentage points less likely to enter a top job while a graduate from a high participation area is 3.9 percentage points more likely to enter a top job than a graduate from an average participation area. The strongest gradient however is observed for those who attend state schools compared to privately educated graduates. Figure 1 plots the private school advantage for each of the five models. As seen in the first bar, before conditioning on any other characteristics, those who attend a private school are 9.5 percentage points more likely to enter a top job 3.5 years after graduation than a state educated graduate.

Columns 2 to 5 build in controls as discussed in equation (2) in the previous section. Adding in demographic controls does very little to the estimated socio-economic gradients across the measures and in some cases accentuates the findings from the raw model. However, when conditioning on prior attainment, including the subject taken at degree and the degree classification, along with their UCAS tariff point score, the socio-economic gradient in access to top jobs is reduced substantially from the previous models. There is little difference now in the probability of accessing a top job by the parents' occupation. Living in a high participation neighbourhood is associated with an additional 2.2 percentage point advantage in accessing an occupation in the top NS-SEC. There is still a stark difference by the type of secondary school attended even when conditioning on prior attainment: state school educated graduates are still 6 percentage points less likely to enter into a top job than a comparable privately educated graduate, who took the same subject and achieved the same grade in their degree (and A-levels). Conditioning on the higher education institution attended further reduces this state school gradient by $45 \%$ : The institution that the graduate attended is playing an important role in accounting for differences in access to top jobs for private and state educated graduates. However, even when accounting for these different choices and conditioning on post-graduate qualifications a significant private school effect remains. As shown in the final column of Figure 1, private school graduates are still 2.5 percentage points (baseline $30 \%$ ) more likely to access a top NS-SEC occupation than a comparable state 
school graduate who has parents from a similar NS-SEC group, is from the same type of neighbourhood, got similar A-levels, and has the same degree classification in the same subject from the same institution and has obtained similar post-graduate qualifications.

We check to see if the large amount of missing data on parental NS-SEC could be driving our findings in some way by repeating our analysis of the final column in Table 3 for a smaller sub-sample where parental NS-SEC is available. Any differences between the two models may indicate that differential responses to the parental NS-SEC question could be driving our results. As can be seen from Appendix Table A3, the main qualitative story remains despite the state school effect becoming insignificantly different from zero. This looks to be largely driven by the increased standard errors as a result of losing around $20 \%$ of the total sample. The differences across the two coefficients are not statistically different from zero at the $99 \%$ level ${ }^{19}$.

Interesting differences in access to high status occupations also exist within the top NS-SEC occupations. Table 4 presents the marginal effects from a multinomial logit model comparing access to a) higher managerial, b) business, legal and life-science occupations and c) education, science, built environment occupations as compared to NS-SEC 2-7 jobs.

Graduates with lower managerial parents are 1.8 percentage points more likely to work in a higher managerial occupation at 3.5 years after graduation than graduates with a parent working in a routine occupation (baseline 6.1\% compared to NS-SEC 2-7 occupations). Those living in high participation neighbourhoods are 0.8 percentage points more likely to work in these top occupations compared to NS-SEC 2-7 occupations as compared to graduates from an average participation neighbourhood. Figure 2 illustrates that the private school advantage is large (blue bars), with privately educated graduates 3.4 percentage points more likely to work in a higher managerial position than state educated graduates from a baseline group size of $6.1 \%$. When we condition on demographics and prior attainment the SES gradients remain intact suggesting that access to these particular occupations are not related to gender, ethnicity, age or indeed prior attainment. Controlling for HE institution effects however, removes any differences by parental NS-SEC although an effect remains for neighbourhood participation and type of school attended. Controlling for postgraduate

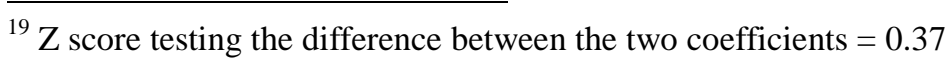


qualifications further reduces the association between the SES variables and the likelihood of securing a higher managerial job. Comparing a like for like privately educated and state educated graduate from the same type of family and neighbourhood, with the same prior attainment, from the same institution, with the same post-graduate qualifications, the privately educated graduate has a 1 percentage point advantage over the state school graduate (on a baseline of $6.1 \%$ of entering a top managerial position 3.5 years after graduation). The neighbourhood HE participation rate and parental SES measures are statistically insignificant.

A similar picture emerges when considering access to business, legal and life science careers although for this grouping the raw private school association is slightly larger (6.2 percentage point advantage on a baseline of 10.5\%) and more of the background effect can be accounted for by prior attainment (Figure 2 - red bars). The significant association between having parents in the top NS-SEC and entering a business, legal or life-science profession disappears once we control for the prior attainment of the graduate. Conditioning on prior attainment and demographics graduates from low participation neighbourhoods are 1.2-1.4 percentage points less likely than graduates from average participation neighbourhoods to enter into business, legal or life science professions (compared to NS-SEC 2-7 occupations). Privately educated graduates are 2.6 percentage points more likely than state school graduates to enter into these occupations. The institution attended accounts for a large part of access to these jobs with $73 \%$ of the remaining private school advantage eradicated with the inclusion of institution effects: where you went to university matters a lot for these types of occupations. However, even when conditioning on all of these variables, including prior attainment, institution and higher qualifications, there is still a significant advantage from a private school education on access to these professional careers: privately educated graduates are 0.3 percentage points more likely to work in these occupations than a comparable state educated graduate.

If we focus on education, build environment, science and other professional occupations, perhaps surprisingly, the private school advantage is reversed as seen in Figure 2 (green bars). Privately educated graduates are 1.7 percentage points less likely than state educated graduates to work in these occupations in the raw model and 1.1 percentage points less likely in the full model (baseline 13.3\%). This finding is perhaps surprising although it could indicate that top state school graduates select into alternative types of careers compared to privately educated graduates or, given the increased likelihood of private school graduates accessing top managerial and business, legal and life science jobs, state school graduates are 
sorted into these other professions.

\section{The role of networks in accessing top jobs}

Given this large socio-economic gap in access to the top jobs, we explore one potential channel through which graduates from higher status families may be gaining preferential access to these occupations; namely through having higher social capital or more networks. By controlling for networks in the model, if this is the main driver of the differences in access to the top jobs by socio-economic status, we would expect the socio-economic gap seen in Tables 3 and 4 to be reduced or eliminated by the inclusion of these variables. Column 1 of Table 5 presents the relationship between socio-economic status and entering a top NS-SEC job before controlling for the use of networks (reproducing the last column of Table 3 ) whilst column 2 conditions on the use of networks (equation (3)). Comparing the two models it is clear that the socio-economic gap in accessing the top jobs remains unchanged whether or not the use of networks is controlled for. Columns 3-8 repeat this analysis from multinomial logit models of the more detailed occupation groupings from Table 4. Columns 3, 5 and 7 repeat columns 5 from Table 4 panels A-C, whilst columns 4, 6 and 8 present the corresponding results including the network variables. In all cases, the inclusion of controls for networks has very little impact on the relationship between family background and entering a top occupation and in some cases, even slightly increases the relationship. This suggests that, when conditioning on a range of background characteristics and potential mechanisms for access to top occupations, networks are orthogonal to socio-economic status; the use of networks is not the main driver of these large gaps in accessing the top jobs by family background $^{20}$.

Interestingly, the use of networks has a significant independent effect on accessing top jobs, over and above socio-economic status and these effects vary by the types of occupations considered. Using a professional network to find out about a job, rather than some other method, increases the probability of working in a top NS-SEC job by 5.3 percentage points compared to working in an NS-SEC 2-7 occupation. Figure 3 plots the association between using networks and access to top jobs by the those entering higher managerial, business, legal and life science professions and education, built environment, scientist and other professions.

\footnotetext{
${ }^{20}$ Indeed the correlation between the type of school attended and the use of networks is low in this data: the correlation between state school attendance and personal networks is 0.01 , professional networks is 0.04 and previously working for the employer is 0.03 .
} 
Looking across types of occupations, this is clearly driven by the use of professional networks in accessing education, built environment, science and other professional careers (green bars). Professional networks have an insignificant effect on access to higher occupations. Access to higher managerial occupations (blue bars) by contrast is significantly improved by the use of personal networks and previous work experience. A graduate who used personal networks to find their job was 0.5 percentage points (baseline 6.1\%) more likely than a graduate who found their job by other means to work in a higher managerial occupation.

\section{Conclusions}

Our findings are stark. There is a large socio-economic gradient in the likelihood of a recent graduate accessing a top job. $40 \%$ of graduates who attended a private school secured a higher status occupation, compared to just $28 \%$ of students from state school backgrounds. In addition, $31 \%$ of graduates who come from higher SES family backgrounds (NS-SEC Group 1 or 2) enter top jobs compared to $27 \%$ from lower SES backgrounds (NS-SEC groups 2-7). Much of this socio-economic gradient is attributable to the fact that more socio-economically advantaged graduates also have higher levels of human capital. Specifically they have higher achievement at A level, are more likely to attend an elite university and take subjects that have greater economic value in the labour market. However, even controlling for these differences in students' human capital, we still find a modest residual socio-economic gradient in access to top jobs. Even when we include a measure of the student's social capital, namely their use of networks to secure their job, the socio-economic gradient remains. Higher SES students are more likely to say they have used a network to secure their job but this does not explain the strong link between socio-economic background and getting a top job.

Hence we add to the existing literature by showing that it is not simply the case that socioeconomically advantaged students are better qualified or use their networks in order to access top jobs. Our work discounts the notion that higher education levels the playing field between students of differing socio-economic backgrounds. Beyond academic achievement, our analysis suggests there are other reasons why wealthier and more advantaged students, and particularly those who attend a private school, are significantly more likely to secure a top job. It may be the case that more advantaged graduates, such as those from private schools, have other forms of capital that are important for accessing top jobs. These could include 
higher unmeasured human capital such as non-cognitive skills, including confidence and selfesteem that help individuals in interviews. Alternatively these graduates could have higher cultural capital that enables them to exhibit desirable behaviours and conversations in the interview setting. Finally, they may have access to greater financial capital that enables them to increase the period of their job search or take unpaid internships and hence increase their likelihood of accessing a top job. To the extent that we cannot measure all these factors, our identification strategy does not entirely eliminate the possibility that graduates are sorted into top jobs on the basis of characteristics unobserved by the researcher. Hence we view this evidence as associational rather than definitively causal. Our work does, however, contribute to the literature by eliminating differences in education achievement and use of social networks as the sole reasons for the differences we observe in graduates' access to top professions. Further research is clearly needed to establish which of these alternative explanations is most important.

The policy implications of this work are important. First and foremost, the research tells us that amongst recent UK graduates, socio-economic background remains a significant factor in explaining why some students secure top jobs. After many decades of policies to try to improve social mobility, and indeed to widen participation in higher education, it remains the case that a student's family background has a major influence on their job and their life chances. The fact that this relationship is largely but not entirely explained by more advantaged students having demonstrably higher levels of human capital would imply that we must strive to achieve greater transparency in hiring practices so we fully understand why socio-economically disadvantaged students are less likely to get a top job. Only when we understand this can we develop policies to address this. 


\section{References}

Association of Graduate Recruiters (2012). Graduate Recruitment Survey 2012, Winter Review.

Bingley, P., Corak, M. and Westergård-Nielsen, N. (2011). The Intergenerational Transmission of Employers in Canada and Denmark. IZA Discussion Paper No. 5593

Björklund, A., Bratsberg, B., Eriksson, T., Jäntti, M., Naylor, R., Raaum, O., Roed, K. and E. Österbacka (2005). 'Intergenerational earnings mobility in the Nordic countries, the United Kingdom and the United States: An overview'. Mimeo Åbo Akademi University, Finland.

Blanden, J. (2006) 'Bucking the trend': What enables those who are disadvantaged in childhood to succeed later in life? DWP Working Paper No.31

Blanden, J. and Machin, S. (2004). 'Educational Inequality and the Expansion of UK Higher Education'. Scottish Journal of Political Economy, 51, 230-249.

Blanden, J., Gregg, P. and Machin, S. (2005). Intergenerational Mobility in Europe and North America. London: Centre for Economic Performance.

Blanden J, Gregg P, Macmillan L. (2013) 'Intergenerational Persistence in Income and Social Class: The Impact of Within-Group Inequality'. John Wiley and Sons Journal of Royal Statistical Society Series A: Statistics in Society, 176 (2), pp. 541-563.

Blanden, J., Goodman, A., Gregg, P. and Machin, S. (2004) "Changes in intergenerational mobility in Britain" in Corak, M. (ed) Generational Income Mobility in North America and Europe

Bratti, M. and Manchini, L. (2003). Differences in early occupational earnings of UK male graduates by degree subject: Evidence from 1980-1993 USR. IZA, DP 890.

Bratti, M., Naylor, R., \& Smith, J. (2005). Variations in the wage returns to a first degree: Evidence from the British Cohort Study 1970. IZA, DP 1631.

Breen, R. and Goldthorpe, J. (1999) 'Class Inequality and meritocracy: a critique of Saunders and an alternative analysis'. British Journal of Sociology. 50, 1-27.

Brewer, M., Dickerson, A., Gambin, L., Green, A., Joyce, R., and Wilson, R. (2012) Poverty and Inequality in 2020: Impact of Changes in the Structure of Employment, UKCES Joseph Rowntree Foundation.

Bukodi, E., and J. H. Goldthorpe. 2011a. "Class Origins, Education and Occupational Attainment in Britain.” European Societies 13 (3): 347-375.

Bukodi, E. and Goldthorpe, J.H. (2011b) 'Social Class Returns to Higher Education: Chances of Access to the Professional and Managerial Salariat for Men in Three British Birth Cohorts', Longitudinal and Life Course Studies, vol 2, pp1-71. Longitudinal and Life Course Studies, vol 2, pp1-71.

Bukodi, E., Dex, S. and Goldthorpe, J.H. (2011) 'The Conceptualisation and Measurement of Occupational Hierarchies: A Review, a Proposal and some Illustrative Analyses', Quality and Quantity, vol. 45, pp623-39.

Cabinet Office (2009). Unleashing Aspirations: The Final Report of the Panel on Fair Access to the Professions. London: Information Policy Team.

Cabinet Office (2011). Opening Doors, Breaking Barriers: A Strategy for Social Mobility. 
London: Information Policy Team.

Cabinet Office (2012). Fair Access to Professional Careers: A Progress Report by the Independent Reviewer on Social Mobility and Child Poverty. London: Information Policy Team.

Cabinet Office (2013). Social Mobility Indicators. [Online]. Available at: http://www.dpm.cabinetoffice.gov.uk/content/social-mobility-indicators. Last accessed 25th August 2013.

Calvó-Armengol A. (2004), "Job Contact Networks" Journal of Economic Theory, Vol 115, pp 191-206.

Calvó-Armengol A. (2007), "Networks in Labor Markets: Wage and employment dynamics and inequality" Journal of Economic Theory, Vol 132, Issue 1, pp 27-46.

Calvó-Armengol A. and M. O. Jackson (2004) "Social Networks in Determining Employment and Wages", American Economic Review, vol. 94(3), pages 426-454.

Casella A. and T. Hanaki (2005) "Information Transmission in Labor Markets. On the Resilience of Personal Referrals" CEPR Discussion Paper, No 4969.

Chan and Goldthorpe, 2007"Class and Status: The conceptual distinction and its empirical relevance”, American Sociological Review 2007, Vol. 72, August, 521-532.

Chevalier, A. (2010). Does higher education quality matter in the UK. Mimeo: Royal Holloway, University of London.

Chevalier, A. (2011). 'Subject choice and earnings of UK graduates'. Economics of Education Review, pp. 1187-1201.

Chowdry, H., Crawford, C., Dearden, L., Goodman, A., and Vignoles, A. (2012) Widening participation in higher education: analysis using linked administrative data, Journal of the Royal Statistical Society: Series A, Volume 176 Issue 2

Chowdry, H., Crawford, C., and Goodman, A. (2010) Drivers and Barriers to Educational Success: Evidence from the Longitudinal Study of Young People in England, Institute for Fiscal Studies Research Report

Coleman, J. S. (1990). Foundations of Social Theory. Cambridge, MA: Harvard University Press.

Confederation of British Industry (2011). Building for Growth: Business Priorities for Education and Skills - Education and Skills Survey.

Corak, M. and Piraino, P. (2010) The Intergenerational Transmission of Employers. IZA Discussion Paper No. 4819

Chowdry, H., Crawford, C. and Vignoles, A. (2013) 'The graduate labour market: wage differences by socio-economic background', mimeo.

Crawford, C. Goodman, A. and Joyce, R. (2010) Explaining the socio-economic gradient in child outcomes: the intergenerational transmission of cognitive skills. Institute for Fiscal Studies, London.

Crawford, C., Johnson, P., Machin, S. and Vignoles, A. (2011). Social Mobility: A Literature Review.

Devine, F., and Li, Y. (2013) The changing relationship between origins,

education and destinations in the 1990s and 2000s, British Journal of Sociology of Education, 
34:5-6, 766-791.

Erikson R. and J. H. Goldthorpe, (2010) 'Has social mobility in Britain decreased? Reconciling divergent findings on income and class mobility' British Journal of Sociology, 61, 211-230.

Ermisch, J. and Nicoletti, C (2005). Intergenerational earnings mobility: changes across cohorts in Britain. ISER Working Paper Series 2005-19, Institute for Social and Economic Research.

Ermisch, J., Jantti, M. and Smeeding, T. (2012) The Intergenerational Transmissions of Advantage, New York: Russell Sage Foundation.

Feinstein, L. (2003a) How early can we predict future education achievement, LSE Centre Piece Summer 2003.

Feinstein, L. (2003b) Inequality in the Early Cognitive Development of Children in the Early 1970 Cohort. Economica, vol 70 (277), pp73-97.

Fernandez, R. and Castilla, E. (2001). "How Much Is That Network Worth? Social Capital in Employee Referral Networks," in Social Capital: Theory and Research. Nan Lin, Karen Cook and Ronald Burt, eds. NY: Aldine De Gruyter, pp. 85-104.

Goodman A., Gregg, P., and Washbrook, E. (2011) Children's educational attainment and the aspirations, attitudes and behaviours of parents and children through childhood in the UK, Longitudinal and Life Course Studies 2011 Volume 2 Issue 1 Pp 1 - 18

Goldthorpe, J. (2013) "Understanding - and Misunderstanding - Social Mobility in Britain: The Entry of the Economists, the Confusion of Politicians and the Limits of Educational Policy." Journal of Social Policy, 42 (3), 431-450.

Goldthorpe, J. and Jackson, M. (2007), 'Intergenerational class mobility in contemporary Britain: political concerns and empirical findings', The British Journal of Sociology, Vol. 58, pp. 525-546

Goldthorpe, J. and McKnight, A. (2006). “The Economic Basis of Social Class.” Pp. 109-36 in Mobility and Inequality: Frontiers of Research from Sociology and Economics, edited by S. Morgan, D. B. Grusky, and G. S. Fields. Stanford, CA: Stanford University Press.

Goldthorpe, J. and Mills, C. (2008) 'Trends in intergenerational class mobility in modern Britain: Evidence from National Surveys, 1972-2005. National Institute Economic Review 2008 205: 83

Gorard, S. (2008) "A Re-consideration of Rates of "Social Mobility" in Britain: Or Why Research Impact is not Always a Good Thing', British Journal of Sociology of Education 29: 317-24.

Granovetter M. (1973) “The Strength of Weak Ties” American Journal of Sociology, 78 (May), pp1360-1380.

Granovetter, M. (1974: 1995). Getting a Job: A Study of Contacts and Careers, first ed., Harvard University Press; Second ed., 1995, Chicago: University of Chicago Press.

Gregg, P., Propper, C., Washbrook, E. (2008) Understanding the relationship between parental income and multiple child outcomes: a decomposition analysis, CMPO working paper 08/193.

Gregg, P., Jonsson, J., Macmillan, L. and Mood, C. (2013) "Understanding income mobility: 
the role of education for intergenerational income persistence in the US, UK and Sweden" Department of Quantitative Social Science Working Paper no. 13/12, Institute of Education.

Gregg, P. and Macmillan, L. (2010) "Family income, education and cognitive ability in the next generation: exploring income gradients in education and test scores for current cohorts of youth" in Longitudinal and Life Course Studies, 2010 Volume 1 Issue 3 pp 259-280.

Gregg, P. and Goodman, A. (2010) Poorer children's educational attainment: How important are attitudes and behaviour? Joseph Rowntree Foundation.

Gregg, P. and Macmillan, L. (2012). Measuring Mobility. University of Bristol.

Haider, S., and Solon, G. (2006). "Life-Cycle Variation in the Association between Current and Lifetime Earnings," American Economic Review, American Economic Association, vol. 96(4), pages 1308-1320, September.

HEFCE (2011). Approaches to measuring employment circumstances of recent graduates.

Higher Education Statistics Agency (HESA) (2009) Technical Report destinations of Leavers from Higher Education (DLHE) Longitudinal Survey 2004/05", http://www.hesa.ac.uk/dox/dlhe_longitudinal/Second_survey/Longitudinal_DLHE_08 09_Technical_Report_FINAL_280709.pdf.

High Fliers Research (2011). The Graduate Market in 2011: Annual Review of Graduate Vacancies \& Starting Salaries at Britain's Leading Employers.

Holzer (1988). "Search Method Use by Unemployed Youth.” Journal of Labor Economics. Vol. 6, No. 1 pp. 1-20.

Ioannides, Y., and Loury, L. (2004) "Job information networks, neighbourhood effects and inequality," Journal of Economic Literature, Vol. 42(4). pp. 1056-1093

Jerrim, J. (2012) The Socio-Economic Gradient in Teenagers' Reading Skills: How Does England Compare with Other Countries? Fiscal Studies, Volume 33 Issue 2.

Kramarz, F. And Skans, O. (2006) "Nepotism at work? Family networks and youth labour market entry" Unpublished manuscript, Symposium of Labor Economics (ESSLE).

Langlands, A. (2005). The Gateways to the Professions Report ('The Langlands Report'). Nottingham: DfES.

Lin, N, 2001. Social Capital: A Theory of Social Structure and Action. Cambridge and New York: Cambridge U. Press.

Loury, Glenn C. (1977). "A Dynamic Theory of Racial Income Differences," in Women, Minorities and Employment Discrimination. PA Wallace and A. Le Mund, eds. Lexington, MA: Lexington Books, Ch. 8.

Loury, L. (2006) "Some Contacts are More Equal Than Others: Informal Networks, Job Tenure, and Wages," Journal of Labor Economics, Vol. 24 (2), pp. 299-318.

Manning, A. and Swaffield, J. (2008), The gender gap in early-career wage growth. The Economic Journal, 118: 983-1024. doi: 10.1111/j.1468-0297.2008.02158.x

Marsden, P. and Gorman, E. (2001). "Social Networks, Job Changes, and Recruitment," in Sourcebook of Labor Markets: Evolving Structure and Processes. Ivar Berg and Ame L. Kalleberg, eds. New York: Kluwer Academic/Plenum Publishers, pp. 467-502. 
Macmillan, L. (2009). Social Mobility and the Professions. Centre for Market and Public Organisation.

Mann, A. (2012). It's Who You Meet: Why Employer Contacts at School Make a Difference to the Employment Prospects of Young Adults.

Montgomery, James D. 1991. Social networks and labor-market outcomes: Toward an economic analysis. American Economic Review 81 (5) pp1408-18

Pissarides, C. (2001) "The Economics of Search," in International Encyclopedia of the Social and Behavioural Sciences, Amsterdam: Elsevier.

Rees A. (1966) "Information Networks in the Labor Market” American Economic Review, Vol 56, Issue 2, pp559-566

Stigler, George J. 1961. "The Economics of Information," Journal of Political Economy. 69 (3), pp. 213-25.

Stigler, George J. 1962. "Information in the Labor Market," Journal of Political Economy. 70 (5 part 2), pp. 94-105.

Sutton Trust (2005) The Educational Background of the UK's Top Solicitors, Barristers and Judges

Sutton Trust (2006) The Educational Backgrounds of Leading Journalists

Walker, I. and Zhu, Y. (2005). 'The college wage premium and the expansion of higher education in the UK'. Scandinavian Journal of Economics, 110, 695-709.

Walker, I. and Zhu, Y. (2011). 'Differences by degree: Evidence of the net financial rates of return to undergraduate studies for England and Wales'. Economics of Education Review, 30, 1177-1186.

Wilson, T. (2012) A Review of Business-University Collaboration.

Wilson, R.A. and Homenidou, K. (2011) Working Futures 2010-2020. Evidence Report 41. Wath-upon-Dearne: UK Commission for Employment and Skills

Wolf, A. (2011) Review of Vocational Education - the Wolf Report. 
Table 1: Family background of those entering into high status professions

\begin{tabular}{rl|rr|rr|rr}
\hline & $\begin{array}{l}\text { Total } \\
\text { frequency } \\
\text { (percent) }\end{array}$ & $\mathbf{1 - 2}$ & $\begin{array}{r}\text { By parental NS- } \\
\text { 3-8 }\end{array}$ & \multicolumn{2}{|c|}{ By participation } & \multicolumn{2}{|c}{ By school type } \\
& & & & & & \\
Top NS-SEC & 29.8 & 62.5 & 37.5 & 6.2 & 93.8 & 83.1 & 16.9 \\
NS-SEC 2-7 & 70.2 & 57.7 & 52.3 & 8.1 & 91.9 & 89.2 & 10.8 \\
Total & 100.0 & & & & & & \\
Within top NS-SEC & & & & & & & \\
\hline Higher managerial & 6.1 & 62.7 & 37.3 & 6.6 & 93.4 & 79.6 & 20.4 \\
NS-SEC 1.1 & & & & & & & \\
Higher professional: & 23.7 & 62.5 & 37.5 & 6.1 & 93.9 & 84.0 & 16.1 \\
NS-SEC 1.2 & & & & & & & \\
Total & 29.8 & & & & & & \\
& & & & & & & \\
Within NS-SEC1.2 & & 61.6 & 38.4 & 5.5 & 94.5 & 76.4 & 23.7 \\
Business & 4.6 & 67.9 & 32.1 & 5.6 & 94.4 & 78.7 & 21.3 \\
Legal & 2.4 & 66.4 & 33.6 & 4.7 & 95.3 & 79.7 & 20.3 \\
\hline Life Science & 3.5 & 66.6 & 33.4 & 5.9 & 94.1 & 87.1 & 12.9 \\
Education & 3.1 & 59.2 & 40.8 & 6.5 & 93.5 & 88.9 & 11.1 \\
Built Environment & 8.4 & 57.5 & 42.6 & 10.6 & 89.4 & 91.8 & 8.2 \\
Scientists & 1.5 & 64.3 & 35.7 & 2.5 & 97.5 & 84.2 & 15.8 \\
Other & 0.3 & & & & & & \\
Total & 23.7 & & & & & & \\
\hline
\end{tabular}

Notes: Row percentages in columns $2+3,4+5$ and $6+7$. Occupations within professional groupings: Business: Accountants, economists, statisticians, brokers, underwriters, tax specialist. Legal: Judges, barristers, solicitors. Life Science: Doctors, dentists, pharmacists, psychologists, veterinarians. Education: Higher education teachers and researchers, secondary and primary head teachers, senior administrators. Build environment: Engineers, IT consultants, architects and surveyors. Scientists: Chemists, biologists, physicists, astronomers, mathematicians. Other: Clergy, probation officers, aircraft pilots

Table 2: How those entering high status occupations found out about their jobs (percent)

\begin{tabular}{rr|rrr|r}
\hline NS-SEC & 1 & 1.1 & 1.2 & 1.2 & $2-7$ \\
\hline Destination outcome: & $\begin{array}{r}\text { Top NS- } \\
\text { SEC job }\end{array}$ & $\begin{array}{r}\text { Higher } \\
\text { managerial }\end{array}$ & $\begin{array}{r}\text { Business, Legal } \\
\text { and Life Science }\end{array}$ & $\begin{array}{r}\text { Other } \\
\text { Professional }\end{array}$ & $\begin{array}{r}\text { Other } \\
\text { graduate } \\
\text { jobs }\end{array}$ \\
Professional networks & 11.2 & & & & \\
Personal networks & 12.4 & 16.1 & 11.1 & 12.5 & 8.2 \\
Previously worked for & 9.2 & 10.4 & 10.5 & 12.1 & 14.3 \\
employer & & & 7.9 & 9.7 & 9.6 \\
Other: & 65.0 & 60.9 & 68.2 & 64.2 & 66.3 \\
Total & 100.0 & 100.0 & 100.0 & 100.0 & 100.0 \\
Within Other & & & & & \\
\hline Career services or web & 38.8 & 30.4 & 44.9 & 37.7 & 38.5 \\
Recruitment agency & 15.9 & 19.5 & 11.6 & 17.7 & 18.1 \\
Other way & 10.3 & 11.0 & 11.7 & 8.8 & 9.7 \\
Total & 65.0 & 60.9 & 68.2 & 64.2 & 66.3 \\
\hline Networks missing & 2.3 & 4.1 & 2.2 & 1.5 & 1.7 \\
\hline
\end{tabular}

Notes: Other professional includes Education, Environment, Scientists and other occupation groups from NS-SEC 1.2. 
Table 3: Marginal effects from a probit model of family background on having a high status occupation (top NS-SEC) 3.5 years after graduation compared to other occupations (NS-SEC 2-7)

\begin{tabular}{|c|c|c|c|c|c|}
\hline Professional & $0.047(.018)^{* * *}$ & $0.066(.018)^{* * *}$ & $0.018(.018)$ & $0.003(.022)$ & $-0.001(.022)$ \\
\hline Lower manager & $0.009(.017)$ & $0.026(.017)$ & $-0.002(.017)$ & $-0.011(.020)$ & $-0.012(.021)$ \\
\hline Intermediate & $-0.001(.018)$ & $0.012(.018)$ & $-0.007(.018)$ & $-0.017(.023)$ & $-0.020(.023)$ \\
\hline Small employer & $-0.007(.020)$ & $0.006(.020)$ & $-0.018(.019)$ & $-0.018(.025)$ & $-0.021(.025)$ \\
\hline Supervisor & $0.014(.022)$ & $0.025(.022)$ & $-0.001(.022)$ & $-0.008(.024)$ & $-0.008(.024)$ \\
\hline Semi-routine & $-0.001(.019)$ & $0.09(.019)$ & $-0.006(.019)$ & $-0.014(.025)$ & $-0.013(.025)$ \\
\hline Routine & Baseline & Baseline & Baseline & Baseline & Baseline \\
\hline Unemployed & $-0.172(.066)^{*}$ & $-0.171(.069)^{* *}$ & $-0.100(.087)$ & $-0.111(.071)$ & $-0.110(.070)$ \\
\hline Low particip. & $-0.031(.013)^{* *}$ & $-0.029(.013)^{* *}$ & $-0.021(.013)$ & $-0.016(.013)$ & $-0.013(.013)$ \\
\hline $2^{\text {nd }}$ quintile part. & $-0.016(.011)$ & $-0.014(.011)$ & $-0.011(.011)$ & $-0.009(.013)$ & $-0.009(.013)$ \\
\hline $3^{\text {rd }}$ quintile part. & Baseline & Baseline & Baseline & Baseline & Baseline \\
\hline $4^{\text {th }}$ quintile part. & 0.009 (.009) & $0.009(.009)$ & $0.006(.010)$ & $0.006(.010)$ & $0.005(.011)$ \\
\hline High particip. & $0.039(.009)^{* * *}$ & $0.036(.009)^{* * *}$ & $0.022(.008)^{* *}$ & $0.015(.010)$ & $0.015(.009)$ \\
\hline State school & $-0.095(.010)^{* * *}$ & $-0.087(.010)^{* * *}$ & $-0.060(.010)^{* * *}$ & $-0.033(.013)^{* *}$ & $-0.025(.013)^{*}$ \\
\hline $\mathrm{N}$ & 24980 & 24980 & 24980 & 24980 & 24980 \\
\hline $\begin{array}{l}\text { Pseudo R- } \\
\text { squared }\end{array}$ & 0.010 & 0.034 & 0.146 & 0.162 & 0.176 \\
\hline \multicolumn{6}{|l|}{ Controls } \\
\hline Demographics & & $\mathrm{x}$ & $\mathrm{X}$ & $\mathrm{X}$ & $\mathrm{x}$ \\
\hline Prior attainment & & & $\mathrm{x}$ & $\mathrm{X}$ & $\mathrm{X}$ \\
\hline Institution & & & & $\mathrm{X}$ & $\mathrm{x}$ \\
\hline Post-grad qual. & & & & & $\mathrm{X}$ \\
\hline
\end{tabular}


Table 4: Marginal effects from a multinomial logit model of family background on having alternative high status occupations 3.5 years after graduation compared to other occupations (NS-SEC 2-7)

\begin{tabular}{|c|c|c|c|c|c|}
\hline \multicolumn{6}{|c|}{ Panel A: Higher managerial (NS-SEC 1.1) - 6.1\% } \\
\hline Professional & $0.012(.010)$ & $0.012(.010)$ & $0.013(.010)$ & $0.004(.005)$ & $0.003(.004)$ \\
\hline Lower manager & $0.018(.010)^{*}$ & $0.018(.010)^{*}$ & $0.018(.010)^{*}$ & $0.006(.005)$ & $0.005(.004)$ \\
\hline Intermediate & $0.015(.011)$ & $0.015(.011)$ & $0.014(.011)$ & $0.004(.005)$ & $0.004(.004)$ \\
\hline Small employer & $0.010(.012)$ & $0.011(.011)$ & $0.010(.012)$ & $0.004(.006)$ & $0.004(.005)$ \\
\hline Supervisor & $0.008(.013)$ & $0.008(.012)$ & $0.010(.013)$ & $0.003(.006)$ & $0.003(.004)$ \\
\hline Semi-routine & $0.006(.011)$ & $0.007(.011)$ & $0.006(.011)$ & $0.001(.006)$ & $0.001(.005)$ \\
\hline Routine & Baseline & Baseline & Baseline & Baseline & Baseline \\
\hline Unemployed & $-0.008(.043)$ & $-0.010(.059)$ & $-0.018(.060)$ & $-0.016(.028)$ & $-0.012(.022)$ \\
\hline Low particip. & $0.002(.007)$ & $0.001(.007)$ & $0.000(.007)$ & $0.001(.003)$ & $0.000(.003)$ \\
\hline $2^{\text {nd }}$ quintile part. & $0.001(.006)$ & $0.001(.006)$ & $0.002(.006)$ & $0.001(.003)$ & $0.001(.003)$ \\
\hline $3^{\text {rd }}$ quintile part. & Baseline & Baseline & Baseline & Baseline & Baseline \\
\hline $4^{\text {th }}$ quintile part. & $0.007(.005)$ & $0.007(.005)$ & 0.007 (.005) & $0.004(.002)^{*}$ & $0.003(.002)^{*}$ \\
\hline High particip. & $0.008(.005)^{*}$ & $0.007(.005)$ & $0.008(.005)^{*}$ & $0.004(.002)^{*}$ & $0.003(.002)^{*}$ \\
\hline State school & $-0.034(.005)^{* * *}$ & $-0.034(.004)^{* * *}$ & $-0.035(.005)^{* * *}$ & $-0.013(.002)^{* * * *}$ & $-0.010(.002)^{* * *}$ \\
\hline \multicolumn{6}{|l|}{ Controls } \\
\hline Demographics & & $\mathrm{x}$ & $\mathrm{x}$ & $\mathrm{x}$ & $\mathrm{x}$ \\
\hline Prior attainment & & & $\mathrm{x}$ & $\mathrm{x}$ & $\mathrm{x}$ \\
\hline Institution & & & & $\mathrm{x}$ & $\mathrm{x}$ \\
\hline Post-grad qual. & & & & & $\mathrm{x}$ \\
\hline \multicolumn{6}{|c|}{ Panel B: Business, Legal and Life Science (NS-SEC 1.2) - 10.5\% } \\
\hline Professional & $0.024(.013)^{* *}$ & $0.035(.012)^{* * *}$ & $0.005(.008)$ & $0.001(.004)$ & $0.000(.002)$ \\
\hline Lower manager & $-0.003(.011)$ & $0.007(.012)$ & $-0.008(.008)$ & $-0.003(.003)$ & $-0.002(.002)$ \\
\hline Intermediate & $0.005(.013)$ & $0.012(.012)$ & $0.002(.009)$ & $-0.000(.004)$ & $-0.001(.002)$ \\
\hline Small employer & $-0.006(.013)$ & $-0.000(.014)$ & $-0.010(.010)$ & $-0.003(.004)$ & $-0.002(.002)$ \\
\hline Supervisor & $-0.006(.015)$ & $0.002(.016)$ & $0.003(.011)$ & $0.001(.004)$ & $-0.000(.002)$ \\
\hline Semi-routine & $-0.012(.012)$ & $-0.009(.014)$ & $-0.005(.009)$ & $-0.002(.004)$ & $-0.001(.002)$ \\
\hline Routine & Baseline & Baseline & Baseline & Baseline & Baseline \\
\hline Unemployed & $-0.072(.045)$ & $-0.078(.095)$ & $-0.002(.056)$ & $-0.005(.016)$ & $0.001(.007)$ \\
\hline Low particip. & $-0.026(.008)^{* * * *}$ & $-0.024(.010)^{* *}$ & $-0.012(.007)^{*}$ & $-0.004(.003)$ & $-0.002(.001)$ \\
\hline $2^{\text {nd }}$ quintile part. & $-0.018(.007)^{* *}$ & $-0.018(.008)^{* *}$ & $-0.014(.006)^{* *}$ & $-0.004(.002)^{* *}$ & $-0.002(.001)^{* *}$ \\
\hline $3^{\text {rd }}$ quintile part. & Baseline & Baseline & Baseline & Baseline & Baseline \\
\hline $4^{\text {th }}$ quintile part. & $-0.004(.006)$ & $-0.003(.006)$ & $-0.004(.004)$ & $-0.002(.002)$ & $-0.001(.001)$ \\
\hline High particip. & $0.016(.006)^{* * *}$ & $0.016(.006)^{* * *}$ & $0.004(.004)$ & $0.000(.002)$ & $0.000(.001)$ \\
\hline State school & $-0.062(.007)^{* * *}$ & $-0.060(.005)^{* * *}$ & $-0.026(.004)^{* * * *}$ & $-0.007(.002)^{* * *}$ & $-0.003(.001)^{* * *}$ \\
\hline \multicolumn{6}{|l|}{ Controls } \\
\hline Demographics & & $\mathrm{x}$ & $\mathrm{x}$ & $\mathrm{x}$ & $\mathrm{x}$ \\
\hline Prior attainment & & & $\mathrm{x}$ & $\mathrm{x}$ & $\mathrm{x}$ \\
\hline Institution & & & & $\mathrm{x}$ & $\mathrm{x}$ \\
\hline Post-grad qual. & & & & & $\mathrm{x}$ \\
\hline
\end{tabular}




\begin{tabular}{|c|c|c|c|c|c|}
\hline \multicolumn{6}{|c|}{ Panel C: Education, Environment, Scientists and Other (NS-SEC 1.2) - 13.3\% } \\
\hline Professional & $0.011(.012)$ & $0.016(.012)$ & $-0.002(.010)$ & $-0.004(.007)$ & $-0.004(.005)$ \\
\hline Lower manager & $-0.005(.012)$ & $0.001(.011)$ & $-0.007(.010)$ & $-0.006(.007)$ & $-0.005(.005)$ \\
\hline Intermediate & $-0.020(.012)$ & $-0.015(.012)$ & $-0.020(.011)^{*}$ & $-0.013(.008)^{*}$ & $-0.011(.006)^{*}$ \\
\hline Small employer & $-0.010(.014)$ & $-0.004(.013)$ & $-0.014(.012)$ & $-0.009(.008)$ & $-0.008(.006)$ \\
\hline Supervisor & $0.011(.015)$ & $0.013(.014)$ & $-0.009(.013)$ & $-0.007(.009)$ & $-0.004(.007)$ \\
\hline Semi-routine & $0.003(.014)$ & $0.010(.013)$ & $-0.004(.011)$ & $-0.005(.008)$ & $-0.004(.006)$ \\
\hline Routine & Baseline & Baseline & Baseline & Baseline & Baseline \\
\hline Unemployed & $-0.162(.118)$ & $-0.160(.112)$ & $-0.091(.011)$ & $-0.066(.060)$ & $-0.052(.047)$ \\
\hline Low particip. & $-0.009(.010)$ & -0.009 (.009) & $-0.007(.008)$ & $-0.003(.006)$ & $-0.002(.004)$ \\
\hline $2^{\text {nd }}$ quintile part. & $-0.000(.008)$ & $0.001(.008)$ & $0.002(.007)$ & $0.001(.005)$ & $0.001(.004)$ \\
\hline $3^{\text {rd }}$ quintile part. & Baseline & Baseline & Baseline & Baseline & Baseline \\
\hline $4^{\text {th }}$ quintile part. & $0.005(.007)$ & $0.003(.006)$ & $0.002(.006)$ & $0.000(.005)$ & $0.000(.003)$ \\
\hline High particip. & $0.014(.006)^{* *}$ & $0.011(.006)^{*}$ & $0.007(.005)$ & $0.003(.004)$ & $0.002(.003)$ \\
\hline State school & $0.017(.007)^{* * *}$ & $0.021(.007)^{* * * *}$ & $0.017(.006)^{* * * *}$ & $0.013(.004)^{* * *}$ & $0.011(.003)^{* * * *}$ \\
\hline \multicolumn{6}{|l|}{ Controls } \\
\hline Demographics & & $\mathrm{x}$ & $\mathrm{x}$ & $\mathrm{x}$ & $\mathrm{x}$ \\
\hline Prior attainment & & & $\mathrm{x}$ & $\mathrm{x}$ & $\mathrm{x}$ \\
\hline Institution & & & & $\mathrm{x}$ & $\mathrm{x}$ \\
\hline Post-grad qual. & & & & & $\mathrm{x}$ \\
\hline $\mathrm{N}$ & 24980 & 24980 & 24980 & 24980 & 24980 \\
\hline $\begin{array}{l}\text { Pseudo R- } \\
\text { Squared }\end{array}$ & 0.011 & 0.037 & 0.185 & 0.208 & 0.226 \\
\hline
\end{tabular}


Table 5: Marginal effects of family background on having a high status occupation 3.5 years after graduation conditioning on the use of networks

\begin{tabular}{|c|c|c|c|c|c|c|c|c|}
\hline & \multicolumn{2}{|l|}{ Top NS-SEC } & \multicolumn{2}{|c|}{ Higher managerial } & \multicolumn{2}{|c|}{$\begin{array}{l}\text { Business, Legal and Life } \\
\text { Science }\end{array}$} & \multicolumn{2}{|c|}{$\begin{array}{l}\text { Education, Environment, } \\
\text { Scientists and Other }\end{array}$} \\
\hline & No networks & Networks & No networks & Networks & No networks & Networks & No networks & Networks \\
\hline Professional & $-0.001(.022)$ & $-0.002(.022)$ & $0.003(.004)$ & $0.004(.005)$ & $0.000(.002)$ & $0.000(.003)$ & $-0.004(.005)$ & $-0.005(.006)$ \\
\hline Lower manager & $-0.012(.021)$ & $-0.012(.021)$ & $0.005(.004)$ & $0.006(.005)$ & $-0.002(.002)$ & $-0.003(.003)$ & $-0.005(.005)$ & $-0.007(.006)$ \\
\hline Intermediate & $-0.020(.023)$ & $-0.021(.023)$ & $0.004(.004)$ & $0.004(.006)$ & $-0.001(.002)$ & $-0.001(.003)$ & $-0.011(.006)^{*}$ & $-0.014(.007)^{*}$ \\
\hline Small employer & $-0.021(.025)$ & $-0.021(.025)$ & $0.004(.005)$ & $0.004(.006)$ & $-0.002(.002)$ & $-0.002(.004)$ & $-0.008(.006)$ & $-0.010(.007)$ \\
\hline Supervisor & $-0.008(.024)$ & $-0.008(.024)$ & $0.003(.004)$ & $0.003(.005)$ & $-0.000(.002)$ & $-0.000(.004)$ & $-0.004(.007)$ & $-0.005(.008)$ \\
\hline Semi-routine & $-0.013(.025)$ & $-0.012(.025)$ & $0.001(.005)$ & $0.001(.006)$ & $-0.001(.002)$ & $-0.002(.004)$ & $-0.004(.006)$ & $-0.004(.007)$ \\
\hline Routine & Baseline & Baseline & Baseline & Baseline & Baseline & Baseline & Baseline & Baseline \\
\hline Unemployed & $-0.110(.070)$ & $-0.112(.070)$ & $-0.012(.022)$ & $-0.013(.027)$ & $0.001(.007)$ & $0.000(.012)$ & $-0.052(.047)$ & $-0.061(.055)$ \\
\hline Low participation & $-0.013(.013)$ & $-0.013(.013)$ & $0.000(.003)$ & $0.001(.003)$ & $-0.002(.001)$ & $-0.003(.002)$ & $-0.002(.004)$ & $-0.002(.005)$ \\
\hline $2^{\text {nd }}$ quintile part. & $-0.009(.013)$ & $-0.009(.013)$ & $0.001(.003)$ & $0.001(.003)$ & $-0.002(.001)^{* *}$ & $-0.004(.002)^{* *}$ & $0.001(.004)$ & $0.001(.005)$ \\
\hline $3^{\text {rd }}$ quintile part. & Baseline & Baseline & Baseline & Baseline & Baseline & Baseline & Baseline & Baseline \\
\hline $4^{\text {th }}$ quintile part. & $0.005(.011)$ & $0.004(.011)$ & $0.003(.002)^{*}$ & $0.004(.002)^{*}$ & $-0.001(.001)$ & $-0.001(.002)$ & $0.000(.003)$ & $-0.001(.004)$ \\
\hline High participation & $0.015(.009)$ & $0.016(.009)^{*}$ & $0.003(.002)^{*}$ & $0.004(.002)^{*}$ & $0.000(.001)$ & $0.001(.001)$ & $0.002(.003)$ & $0.003(.003)$ \\
\hline State school & $-0.025(.013)^{*}$ & $-0.024(.013)^{*}$ & $-0.010(.002)^{* * *}$ & $-0.012(.002)^{* * *}$ & $-0.003(.001)^{* * *}$ & $-0.005(.002)^{* * *}$ & $0.011(.003)^{* * *}$ & $0.013(.004)^{* * *}$ \\
\hline Prof. network & & $0.053(.012)^{* * *}$ & & 0.003 & & $0.002(.011)$ & & $0.017(.004)^{* * *}$ \\
\hline Pers. network & & $-0.010(.012)$ & & $0.005(.002)^{* * *}$ & & $-0.001(.009)$ & & $-0.010(.004)^{* *}$ \\
\hline Prev. worked & & $-0.003(.010)$ & & $0.005(.003)^{*}$ & & $-0.005(.002)^{* *}$ & & $-0.000(.004)$ \\
\hline \multicolumn{9}{|l|}{ Controls } \\
\hline Demographics & $\mathrm{X}$ & $\mathrm{X}$ & $\mathrm{x}$ & $\mathrm{X}$ & $\mathrm{X}$ & $\mathrm{x}$ & $\mathrm{X}$ & $\mathrm{X}$ \\
\hline Prior attainment & $\mathrm{x}$ & $\mathrm{x}$ & $\mathrm{x}$ & $\mathrm{x}$ & $\mathrm{x}$ & $\mathrm{x}$ & $\mathrm{x}$ & $\mathrm{x}$ \\
\hline Institution & $\mathrm{X}$ & $\mathrm{X}$ & $\mathrm{x}$ & $\mathrm{x}$ & $\mathrm{X}$ & $\mathrm{x}$ & $\mathrm{x}$ & $\mathrm{x}$ \\
\hline Post-grad qual. & $\mathrm{x}$ & $\mathrm{x}$ & $\mathrm{x}$ & $\mathrm{x}$ & $\mathrm{x}$ & $\mathrm{x}$ & $\mathrm{x}$ & $\mathrm{x}$ \\
\hline $\mathrm{N}$ & 24980 & 24980 & 24980 & 24980 & 24980 & 24980 & 24980 & 24980 \\
\hline Log likelihood & 0.176 & 0.177 & 0.226 & 0.229 & 0.226 & 0.229 & 0.226 & 0.229 \\
\hline
\end{tabular}

othographics: Gender, age, ethnicity. Prior attainment: UCAS tariff, subject, attainment. Institution: Institution fixed effects, region of institution. Post-grad: Higher research, taught, post-grad certificate /diploma or
other at 3 years. Standard errors are clustered at institution level. * $90 \%$ confidence, $* * 95 \%$ confidence, $* * * 99 \%$ confidence. First two columns from probit models. Other six columns from multinomial probit models. 
Figure 1 Marginal effects of private school attendance on having a high status occupation (top NS-SEC) 3.5 years after graduation compared to other occupations (NS-SEC 2-7)

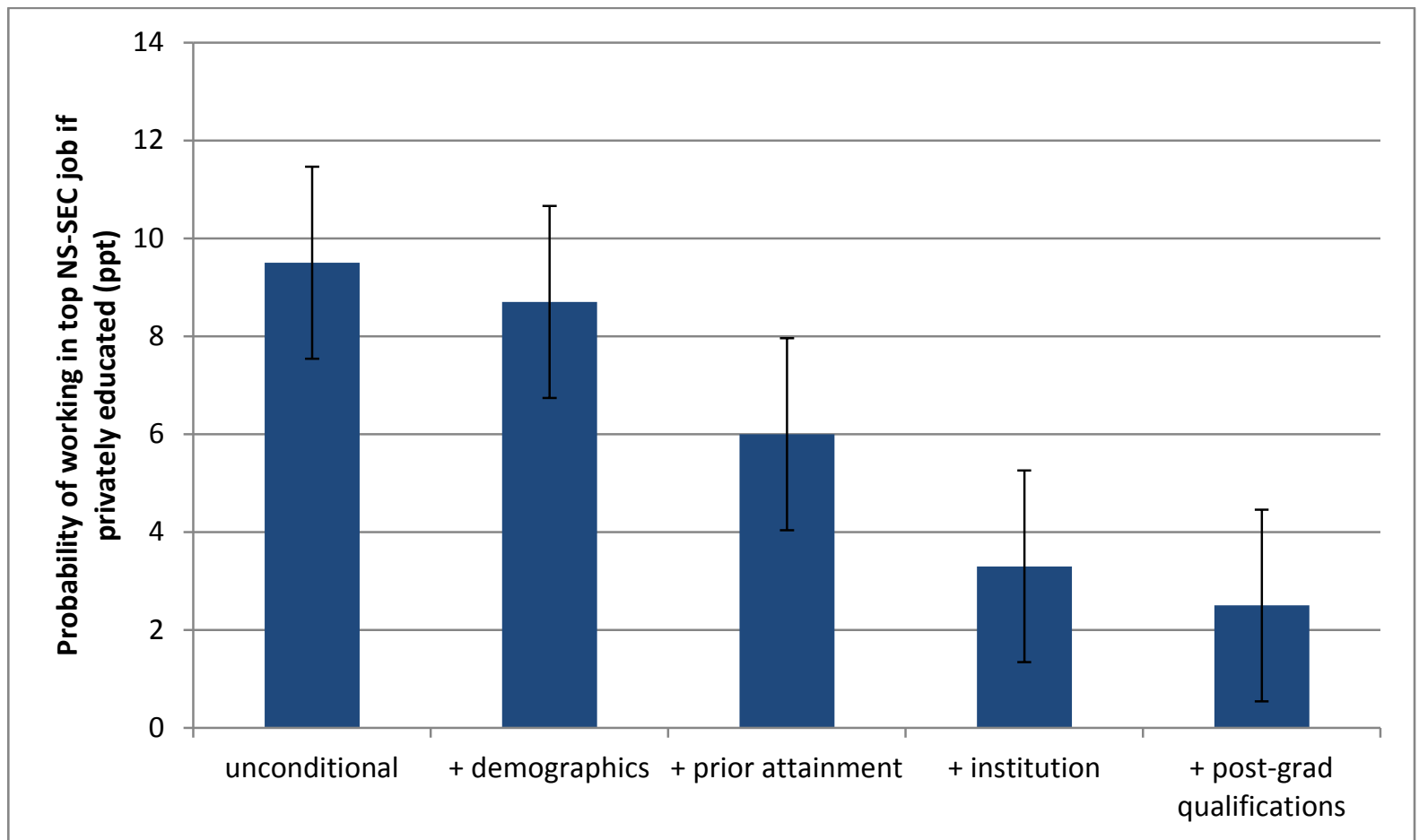

Demographics: Gender, age, ethnicity. Prior attainment: UCAS tariff, subject, attainment. Institution: Institution fixed effects , region of institution. Post-grad: Higher research, taught, post-grad certificate /diploma or other at 3 years.

Figure 2 Marginal effects of private school attendance on having alternative high status occupations 3.5 years after graduation compared to other occupations (NS-SEC 2-7)

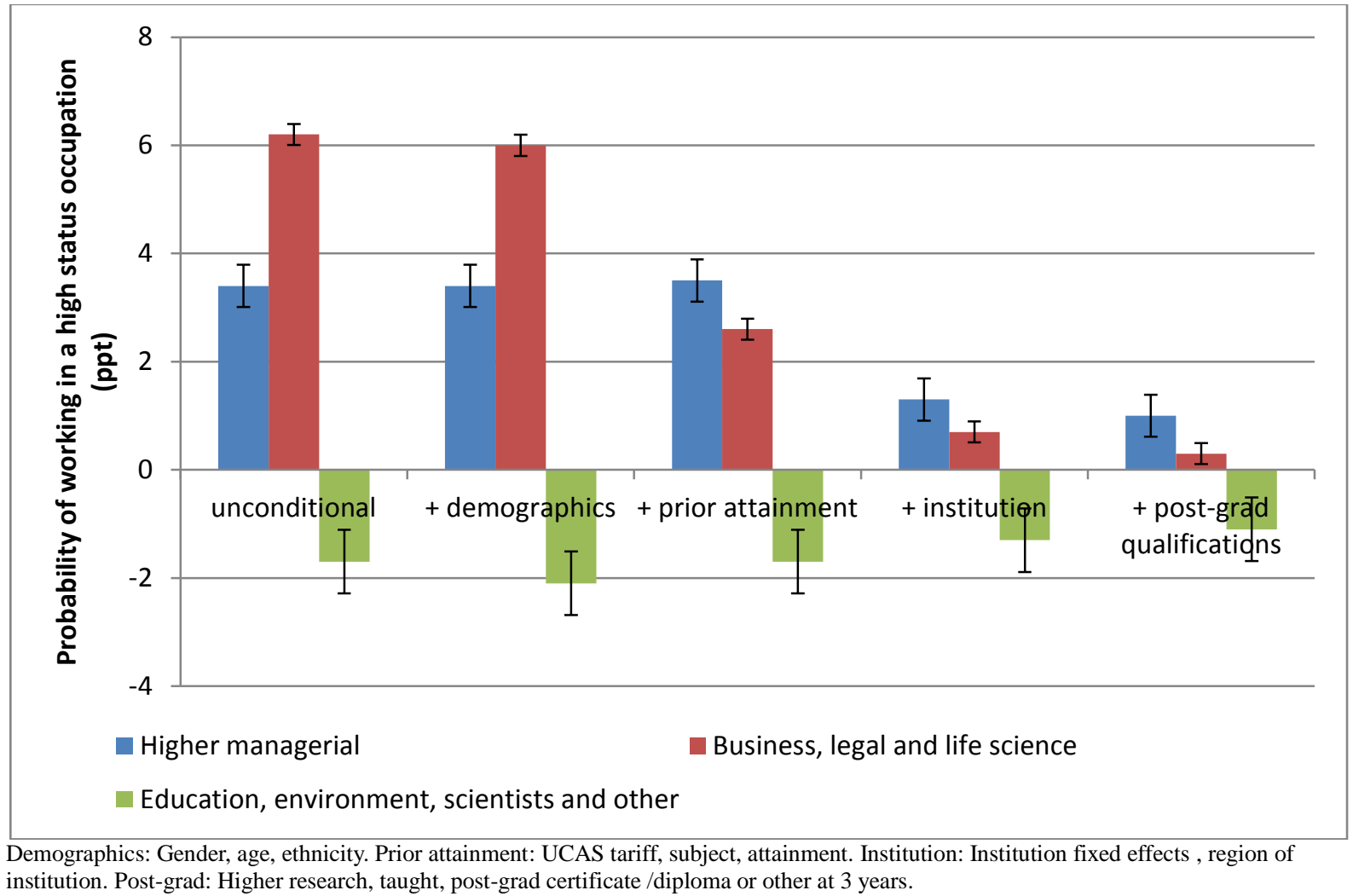


Figure 3 Marginal effects of the use of networks to found out about a job on having a high status occupation 3.5 years after graduation

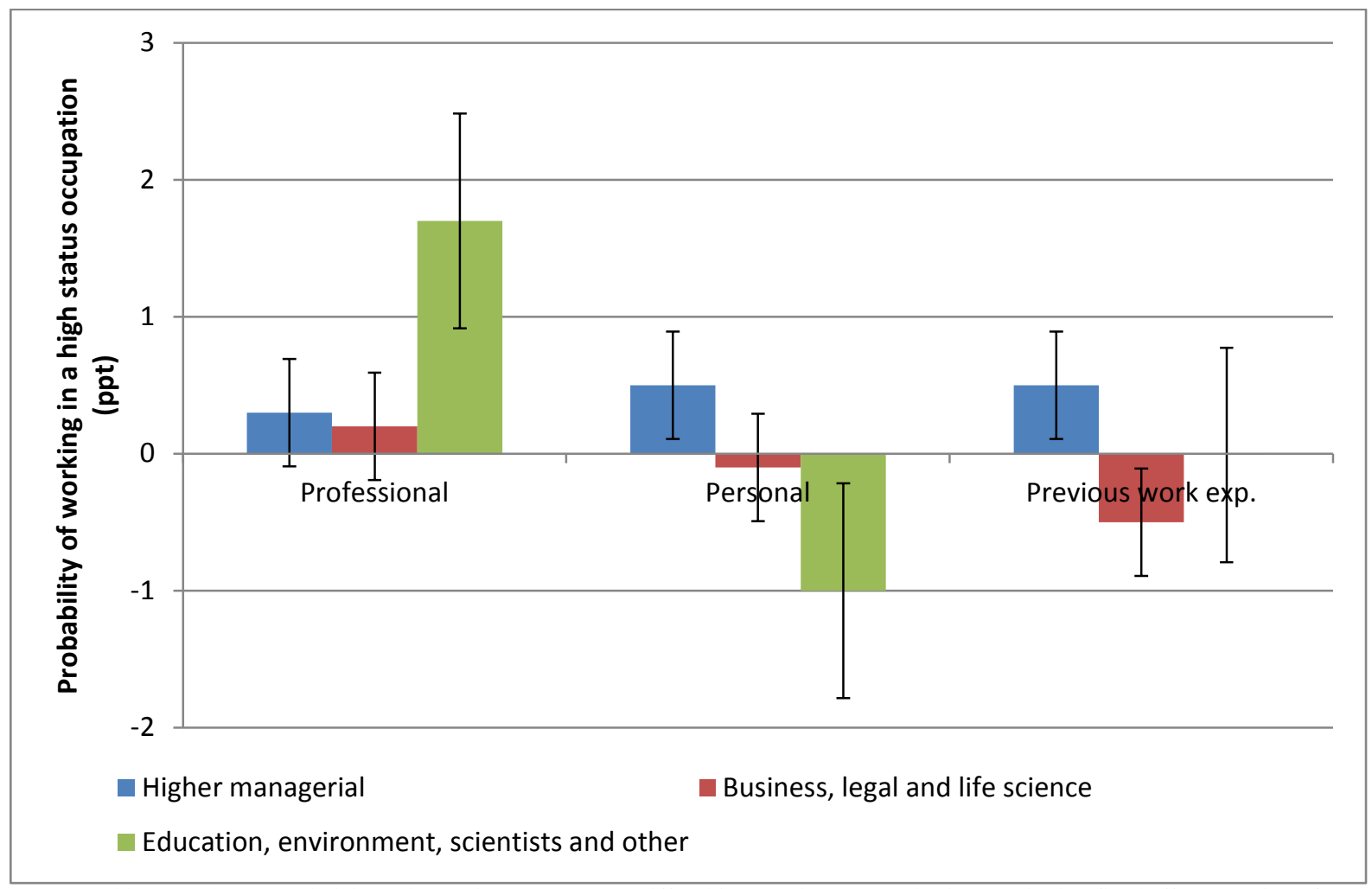

Demographics: Gender, age, ethnicity. Prior attainment: UCAS tariff, subject, attainment. Institution: Institution fixed effects , region of institution. Post-grad: Higher research, taught, post-grad certificate/diploma or other at 3 years. 


\section{Appendix}

Occupations within professional groupings:

Business: Accountants, economists, statisticians, brokers, underwriters, tax specialist.

Legal: Judges, barristers, solicitors.

Life Science: Doctors, dentists, pharmacists, psychologists, veterinarians.

Education: Higher education teachers and researchers, secondary and primary head teachers, senior administrators.

Built environment: Engineers, IT consultants, architects, surveyors.

Scientists: Chemists, biologists, physicists, astronomers, mathematicians.

Other: Clergy, probation officers, aircraft pilots

Table A1: Differences in the social origins of those in the early HESA sample and those in the later longitudinal sample

\begin{tabular}{rrr}
\hline & $\begin{array}{r}\text { Longitudinal } \\
\text { sample }\end{array}$ & Early sample only \\
& & \\
Parents' NS-SEC & & \\
Professional & 13.1 & 12.3 \\
Lower manager & 16.3 & 16.3 \\
Intermediate & 7.9 & 7.7 \\
Small employer & 3.8 & 3.7 \\
Supervisor & 2.4 & 2.6 \\
Semi-routine & 5.3 & 5.8 \\
Routine & 2.4 & 2.6 \\
Unemployed & 0.1 & 0.1 \\
SEC missing & 48.8 & 49.0 \\
Low participation & & \\
$2^{\text {nd }}$ quintile part. & 7.7 & 8.7 \\
$3^{\text {rd }}$ quintile part. & 12.6 & 13.3 \\
$4^{\text {th }}$ quintile part. & 18.1 & 18.4 \\
High participation & 23.1 & 22.7 \\
Low particip. missing & 31.8 & 30.8 \\
State school & 6.6 & 6.2 \\
Private school & & \\
School type missing & 60.2 & 53.6 \\
\hline Percentages based on the entire sample of respondents before additional restrictions applied including aged 18-25, must be an undergraduate \\
leaver in 2006/7 and must have a 5 digit SOC 2000 code at 3.5 years.
\end{tabular}


Table A2: Social origins of those entering the top professions

\begin{tabular}{lr|rrr|r}
\hline \multicolumn{1}{c}{ NS-SEC } & 1 & 1.1 & 1.2 & 1.2 & $2-7$ \\
\hline Destination outcome: & $\begin{array}{r}\text { Top NS- } \\
\text { SEC job }\end{array}$ & $\begin{array}{r}\text { Higher } \\
\text { managerial }\end{array}$ & $\begin{array}{r}\text { Business, } \\
\text { Legal and } \\
\text { Life Science }\end{array}$ & $\begin{array}{r}\text { Other } \\
\text { Professional }\end{array}$ & $\begin{array}{r}\text { Other } \\
\text { graduate } \\
\text { jobs }\end{array}$ \\
Parents' NS-SEC & & & & & \\
Professional & 25.2 & 23.2 & 27.2 & 24.6 & 20.7 \\
Lower manager & 25.6 & 28.9 & 23.3 & 25.9 & 26.2 \\
Intermediate & 11.3 & 12.5 & 11.3 & 10.7 & 12.5 \\
Small employer & 5.6 & 5.9 & 5.2 & 5.8 & 6.4 \\
Supervisor & 3.6 & 3.4 & 3.0 & 4.3 & 4.0 \\
Semi-routine & 6.7 & 6.4 & 5.5 & 7.8 & 7.7 \\
Routine & 3.1 & 2.7 & 2.8 & 3.6 & 3.8 \\
Unemployed & 0.0 & 0.1 & 0.0 & 0.0 & 0.1 \\
SEC missing & 18.8 & 17.0 & 21.7 & 17.3 & 18.8 \\
& & & & & \\
Low participation & 5.9 & 6.3 & 5.0 & 6.4 & 7.8 \\
$2^{\text {nd }}$ quintile part. & 10.5 & 10.7 & 9.2 & 11.5 & 12.9 \\
$3^{\text {rd }}$ quintile part. & 16.2 & 15.3 & 16.1 & 16.6 & 18.0 \\
$4^{\text {th }}$ quintile part. & 23.2 & 24.3 & 22.0 & 23.7 & 24.1 \\
High participation & 38.9 & 38.0 & 41.8 & 37.1 & 33.6 \\
Low particip. missing & 5.3 & 5.5 & 5.8 & 4.8 & 3.6 \\
& & & & & \\
State school & 72.4 & 69.1 & 68.5 & 76.9 & 78.5 \\
Private school & 14.8 & 17.8 & 19.3 & 9.8 & 9.5 \\
State school missing & 12.9 & 13.1 & 12.2 & 13.3 & 12.1 \\
\hline Percentages based on our final sample once additional restrictions applied including aged 18-25, must be an undergraduate leaver in 2006/7 \\
and must have a 5 digit SOC 2000 code at 3.5 years. & & & &
\end{tabular}


Table A3: Marginal effects of family background on having a high status (top NS-SEC) occupation 3.5 years after graduation for those with non-missing parental SEC

\begin{tabular}{|c|c|c|}
\hline & Full sample & $\begin{array}{l}\text { Non-missing } \\
\text { parental SEC }\end{array}$ \\
\hline Professional & $-0.001(.022)$ & $-0.004(.022)$ \\
\hline Lower manager & $-0.012(.021)$ & $-0.014(.021)$ \\
\hline Intermediate & $-0.020(.023)$ & $-0.023(.023)$ \\
\hline Small employer & $-0.021(.025)$ & $-0.024(.025)$ \\
\hline Supervisor & $-0.008(.024)$ & $-0.010(.024)$ \\
\hline Semi-routine & $-0.013(.025)$ & $-0.014(.025)$ \\
\hline Routine & Baseline & Baseline \\
\hline Unemployed & $-0.110(.070)$ & $-0.112(.070)$ \\
\hline Low participation & $-0.013(.013)$ & $-0.011(.013)$ \\
\hline $2^{\text {nd }}$ quintile part. & $-0.009(.013)$ & $-0.010(.013)$ \\
\hline $3^{\text {rd }}$ quintile part. & Baseline & Baseline \\
\hline $4^{\text {th }}$ quintile part. & $0.005(.011)$ & $0.002(.011)$ \\
\hline High participation & $0.015(.009)$ & $0.014(.009)$ \\
\hline State school & $-0.025(.013)^{*}$ & $-0.018(.014)$ \\
\hline \multicolumn{3}{|l|}{ Controls } \\
\hline Demographics & $\mathrm{x}$ & $\mathrm{x}$ \\
\hline Prior attainment & $\mathrm{x}$ & $\mathrm{x}$ \\
\hline Institution & $\mathrm{x}$ & $\mathrm{x}$ \\
\hline Post-grad qual. & $\mathrm{x}$ & $\mathrm{x}$ \\
\hline $\mathrm{N}$ & 24980 & 20297 \\
\hline Pseudo R-squared & 0.176 & 0.166 \\
\hline
\end{tabular}


Table A4: Marginal effects of family background on having a high status (top NS-SEC) occupation 3.5 years after graduation by gender

\begin{tabular}{|c|c|c|}
\hline & Males & Females \\
\hline Professional & $-0.029(.027)$ & $0.017(.030)$ \\
\hline Lower manager & $-0.026(.027)$ & 0.009 (.028) \\
\hline Intermediate & $-0.041(.030)$ & $-0.005(.031)$ \\
\hline Small employer & $-0.038(.031)$ & $-0.008(.032)$ \\
\hline Supervisor & $-0.030(.035)$ & $0.007(.034)$ \\
\hline Semi-routine & $-0.017(.031)$ & $-0.008(.031)$ \\
\hline Routine & Baseline & Baseline \\
\hline Unemployed & $-0.327(.001)$ & $0.074(.086)$ \\
\hline Low participation & $-0.037(.024)$ & $0.012(.020)$ \\
\hline $2^{\text {nd }}$ quintile part. & $-0.029(.019)$ & $0.012(.017)$ \\
\hline $3^{\text {rd }}$ quintile part. & Baseline & Baseline \\
\hline $4^{\text {th }}$ quintile part. & $-0.030(.017)^{*}$ & $0.033(.014)^{* *}$ \\
\hline High participation & $-0.004(.014)$ & $0.033(.012)^{* * *}$ \\
\hline State school & $-0.016(.025)$ & $-0.029(.011)^{* * *}$ \\
\hline \multicolumn{3}{|l|}{ Controls } \\
\hline Demographics & $\mathrm{x}$ & $\mathrm{x}$ \\
\hline Prior attainment & $\mathrm{x}$ & $\mathrm{x}$ \\
\hline Institution & $\mathrm{x}$ & $\mathrm{x}$ \\
\hline Post-grad qual. & $\mathrm{x}$ & $\mathrm{x}$ \\
\hline $\mathrm{N}$ & 10664 & 14316 \\
\hline Pseudo R-squared & 0.148 & 0.194 \\
\hline
\end{tabular}

